\title{
Muscarinic Receptor Activation Stimulates B-50/GAP43 Phosphorylation in Isolated Nerve Growth Cones
}

\author{
C. O. M. Van Hooff, P. N. E. De Graan, A. B. Oestreicher, and W. H. Gispen \\ Divison of Molecular Neurobiology, Rudolf Magnus Institute and Institute of Molecular Biology and Medical Biotechnology, \\ University of Utrecht, $3584 \mathrm{CH}$ Utrecht, The Netherlands
}

\begin{abstract}
A characteristic feature of neurite formation is high expression of the phosphoprotein B-50/GAP43. Previous studies with growth cone membranes have indicated that this neuron-specific protein kinase $\mathbf{C}$ substrate may be involved in transmembrane signal transduction at the growth cone. We monitored the degree of phosphorylation of B-50 by quantitative B-50 immunoprecipitation from intact nerve growth cones, isolated from 5-day-old rat brain and prelabeled with ${ }^{32} \mathrm{P}$-orthophosphate. B-50 phosphorylation in nerve growth cones is stimulated by $4 \beta$-phorbol 12,13 -dibutyrate (PDB) and 1,2-dioctanoylglycerol (DOG) in a concentration-dependent manner, but not by $4 \alpha$-phorbol 12,13 -didecanoate ( $4 \alpha$ PDD). These results confirm that B-50 is a substrate of PKC in intact growth cones. Depolarization induced by $30 \mathrm{~mm} \mathrm{~K} \mathrm{~K}^{+}$ produces a transient increase in B-50 phosphorylation, which is maximal after $15 \mathrm{sec}$ and declines to basal level within 5 min. This rise in B-50 phosphorylation can be partially blocked by atropine $\left(10^{-3}-10^{-4} \mathrm{M}\right)$, suggesting the involvement of muscarinic receptors.

Indeed, the cholinergic receptor agonist carbachol enhances $\mathrm{B}-50$ phosphorylation in a concentration-dependent manner $\left(50 \%\right.$ at $\left.10^{-3} \mathrm{M}\right)$. Since the effect of carbachol $\left(10^{-3}\right.$ M) can be blocked by atropine $\left(10^{-7} \mathrm{M}\right)$, we conclude that this increase in B-50 phosphorylation is mediated through activation of the muscarinic receptors on the growth cones. The carbachol-induced stimulation is further increased by concurrent $\mathrm{K}^{+}$-depolarization. The effects of carbachol and depolarization are additive. To our knowledge, this is the first report showing receptor-mediated effects on the PKC substrate B-50 in growth cones. Our data support the hypothesis that phosphorylation of B-50 by PKC is involved in signal transduction in nerve growth cones.
\end{abstract}

Nerve growth cones are the highly motile tips of axons and dendrites that guide the trailing neurite to the target. The direction of movement of the growth cone can be influenced by many external factors, such as growth factors and substrate molecules (Gunderson and Barrett, 1980; Davis et al., 1985; Kapfhammer and Raper, 1987). Depolarization and neurotrans-

\footnotetext{
Received Nov. 28, 1988; revised Mar. 24, 1989; accepted May 5, 1989

We thank Marina De Wit and Enrique Alonso de Velasco for their excellent technical assistance, Ed Kluis and Paul van der Most for preparing the figures, and Lodewijk Dekker for valuable discussions and suggestions.

Correspondence should be addressed to P. N. E. De Graan, Division of Molecular Neurobiology, Institute of Molecular Biology and Medical Biotechnology, Universily of Utrecht, Padualaan 8, $3584 \mathrm{CH}$ Utrecht, The Netherlands.

Copyright (C) 1989 Society for Neuroscience $0270-6474 / 89 / 113753-07 \$ 02.00 / 0$
}

mitters are both presumed to modulate neurite outgrowth and maturation of a growth cone into a synaptic terminal (Cohan and Kater, 1986; Cohan et al., 1987; Mattson, 1988). This implies that the same signaling systems that mediate communication in the mature nervous system contribute to its developmental construction. Evidence exists that the major site of neurotransmitter action is the growth cone (Haydon et al., 1984; Mattson, 1988). Indeed, growth cones have been shown to carry receptors for several neurotransmitters (Lockerbie and GordonWeeks, 1985; Lockerbie et al., 1988a, b) and to store neurotransmitters, which they release either spontaneously or on depolarization (Hume et al., 1983; Young and Poo, 1983; Gordon-Weeks et al., 1984; Lockerbie et al., 1985).

The response to neurotransmitters requires receptors and highly specialized signal transduction mechanisms, about which little is known in the growth cones. It has been shown that isolated growth cones contain the machinery for cAMP-depcndent signal transduction, since dopamine and vasointestinal peptide stimulate growth cone adenylate cyclase activity (Lockerbie et al., 1988a). There is also evidence that calcium is a second messenger in the transduction pathway of neurotransmitters in growth cones (Cohan et al., 1987; Kater et al., 1988). In vitro phosphorylation studies using $\gamma^{32} \mathrm{P}-\mathrm{ATP}$ ) on isolated growth cones have shown the presence of the machinery for the polyphosphoinositide (PPI) response, since they contain an active PPI metabolism and are capable of generating inositol trisphosphate ( $\mathrm{IP}_{3}$, Pfenninger et al., 1986; Hyman and Pfenninger, 1987; Van Hooff et al., 1988). Furthermore, the major neuronal calcium, calcium/calmodulin, and calcium/phospholipid-dependent protein kinases are present in isolated growth cones (Ellis et al., 1985; Katz et al., 1985; Hyman and Pfenninger, 1987; Van Hooff et al., 1988). This suggests the presence of effector pathways that extend beyond second messengers.

In nerve growth cone membranes of rat brain, B-50/GAP43 is a major phosphoprotein and a substrate for endogenous calcium/phospholipid-dependent protein kinase $\mathrm{C}(\mathrm{PKC})$ (De Graan et al., 1985; Katz et al., 1985; Meiri et al., 1986; Skene et al., 1986; Hyman and Pfenninger, 1987; Van Hooff et al., 1988). From studies on synaptosomal plasma membranes from adult rat brain, a feedback function for B-50 phosphorylation in the PPI response has been proposed (Gispen et al., 1985). A comparable inverse relationship between $\mathrm{B}-50$ phosphorylation and PPI metabolism has been shown to exist in growth cone membranes (Van Hooff et al., 1988).

Stimulation of muscarinic receptors by carbachol induces a PPI response in CNS neurons in culture (Weiss et al., 1988), in brain slices (Brown et al., 1984; Kendall and Nahorski, 1984; Batty et al., 1985; Eva and Costa, 1986; Heacock et al., 1987; 


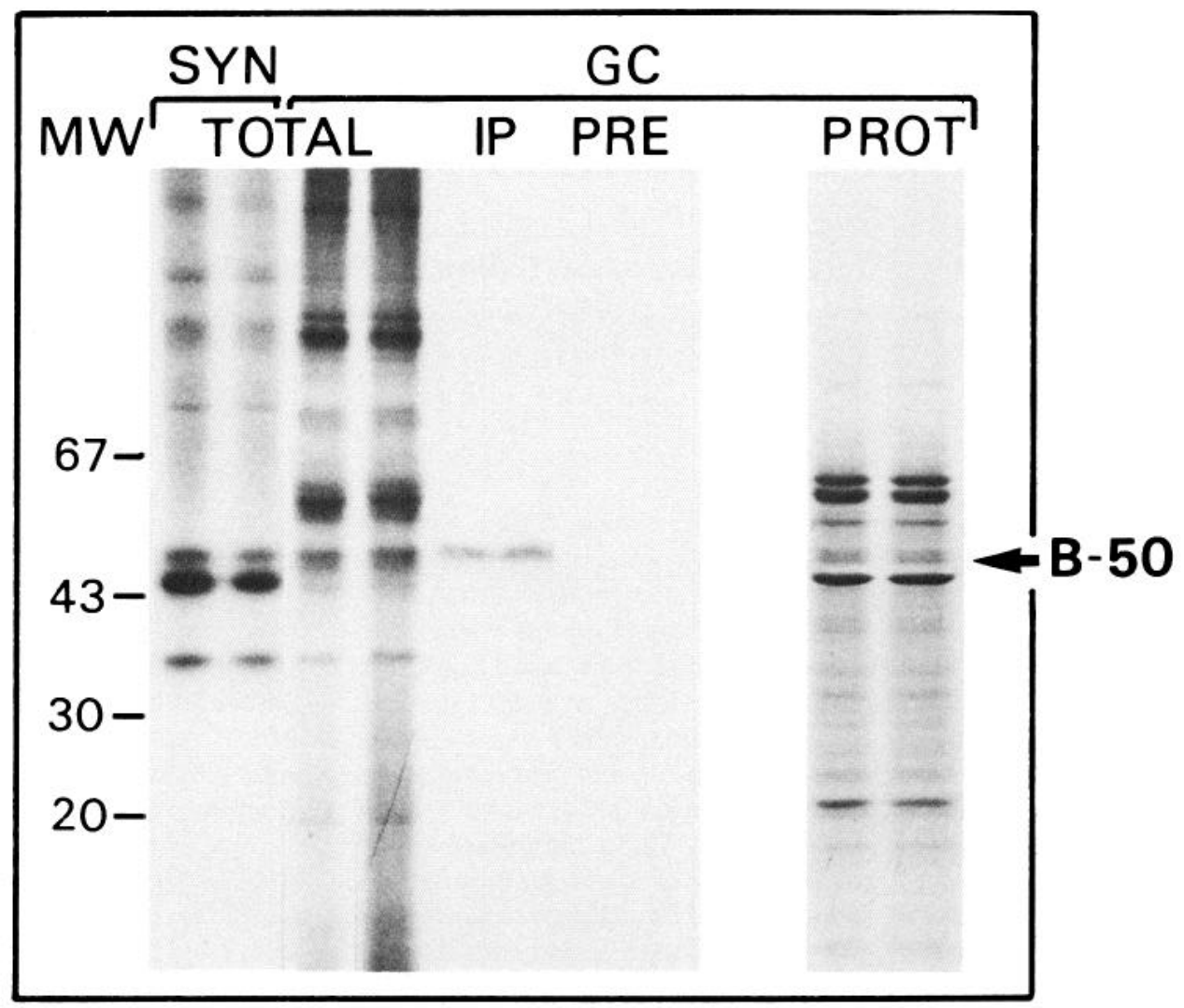

Figure 1. Immunoprecipitation of B-50 from ${ }^{32} \mathrm{P}$-labeled growth cone homogenates. Autoradiogram of SDSPAGE-separated homogenate protein (lanes TOTAL, $0.5 \mu \mathrm{g}$ ) from ${ }^{32} \mathrm{P}$-labeled growth cones $(G C)$ and synaptosomes $(S Y N)$. B-50 was immunoprecipitated from $6.66 \mu \mathrm{g}$ prelabeled growth cone homogenates with B-50 antiserum (IP) or preimmune antiserum $(P R E)$. On the right, fast green-stained protein pattern of total growth cone homogenate $(P R O T, 10 \mu \mathrm{g})$. Positions of molecular weight markers $(M W)$ are indicated on the left.
Jope et al., 1987), and in synaptosomes (Fisher and Agranoff, 1980; Audigier et al., 1988). The evidence that receptor-mediated PPI hydrolysis also results in diacylglycerol (DG) production and the subsequent activation of $\mathrm{PKC}$ is scarce and largely based on the use of phorbol diesters. By monitoring the PKC substrate B-50, we now present evidence for a coupling between muscarinic receptor activation and $\mathrm{PKC}$ activation in growth cones. Both $\mathrm{K}^{+}$-induced depolarization and muscarinic receptor activation by carbachol enhance B- 50 phosphorylation in ${ }^{32} \mathrm{P}$-orthophosphate prelabeled nerve growth cones. The effect of carbachol is dose-dependent and can be blocked by atropine. The effects of carbachol and depolarization appear to be additive.

\section{Materials and Methods}

Isolation of growth cones and synaptosomes. Growth cone-enriched subcellular fractions were isolated from 5-d-old (day of birth is day 1) forebrains of Wistar rats (TNO, Zeist, The Netherlands), as described by Gordon-Weeks and Lockerbie (1984), omitting the second Ficoll step as suggested by Gordon-Weeks (1987). For carbachol and atropine incubations, growth cones were prepared from the cerebral cortex instead of from total forebrains. Isolated growth cones were resuspended in freshly carbogene $\left(95 \% \mathrm{O}_{2}, 5 \% \mathrm{CO}_{2}\right)$-gassed Krebs Ringer buffer, $\mathrm{pH}$ 7.4 without phosphate $\left(\mathrm{KRB}^{-}\right)$and kept at room temperature (max. 1 $\mathrm{hr}$ ) until prelabeling with ${ }^{32} \mathrm{P}$-orthophosphate. Synaptosomes were prepared from rat brain cortex using a discontinuous Percoll/sucrose gradient according to the method of Dunkley et al. (1987). Synaptosomes also were resuspended in freshly gassed $\mathrm{KRB}^{-}$but were kept at $4^{\circ} \mathrm{C}$ until prelabeling with ${ }^{32} \mathrm{P}$-orthophosphate. Ultrastructural analysis revealed that nerve growth cones, isolated from 5-d-old rat brain and kept in $\mathrm{KRB}^{-}$at room temperature for several hours, remain intact and resemble those originally described by Gordon-Weeks and Lockerbie (1984; Van Lookeren Campagne et al., 1989). Protein was determined according to the method of Bradford (1976) using BSA as standard.

Prelabeling of growth cones and synaptosomes with ${ }^{32} P$-orthophos- phate. Growth cones and synaptosomes were labeled batchwise in 200$800 \mu \mathrm{l} \mathrm{KRB}{ }^{-}$with ${ }^{32} \mathrm{P}$-orthophosphate $(3000 \mathrm{Ci} / \mathrm{mmol}$; Amersham) at final concentrations of $1 \mu \mathrm{g}$ protein per $\mu \mathrm{l}$ and $2 \mu \mathrm{Ci} / \mu \mathrm{l}$ for $90 \mathrm{~min}$ at $34^{\circ} \mathrm{C}$ under continuous carbogene gassing. Trichloroacetic acid (TCA) precipitation revealed that ${ }^{32} \mathrm{P}$-incorporation into proteins reaches steady state after about $75 \mathrm{~min}$. Trichloroacetic acid precipitation (De Graan et al., 1989) revealed that under these conditions approximately 35,000 ${ }_{C P M}{ }^{32} \mathrm{P}$ was incorporated per microgram total growth cone protein.

Modulation of B-50 phosphorylation. Aliquots of $10 \mu \mathrm{l}{ }^{32} \mathrm{P}$-labeled growth cones were incubated for the times indicated at $34^{\circ} \mathrm{C}$ in the absence or presence of the modulator (final volume $20 \mu \mathrm{l}$ ). The reaction was stopped by addition of $10 \mu \mathrm{l}$ SDS-denaturing solution (Zwiers et al., 1976) and cooled on ice. Chemical depolarization was induced with $30 \mathrm{~mm} \mathrm{~K}^{+}$( $\mathrm{NaCl}$ was substituted by $25 \mathrm{~mm} \mathrm{~K}^{+}$to maintain osmolarity). Potassium was added at different times (as indicated) prior to the denaturing solution. When $\mathrm{K}^{+}$-depolarization was tested in combination with other agents, $\mathrm{K}^{+}$was added $15 \mathrm{sec}$ before the denaturing solution. Incubations with $4 \alpha$-phorbol 12,13-didecanoate ( $4 \alpha$-PDD; Sigma) or 4 $\beta$-phorbol 12,13-dibutyrate (PDB; Sigma) lasted $10 \mathrm{~min}$, with 1 , 2-dioctanoyl glycerol (DOG; Boehringer) or atropine (O.P.G., Utrecht, The Netherlands) $5 \mathrm{~min}$, and with carbachol (carbamylcholine, Sigma) $5 \mathrm{~min}$ or $30 \mathrm{sec}$.

Quantification of ${ }^{32} P$-incorporation into $B$-50. Incorporation of ${ }^{32} \mathrm{P}$ in B-50 was determined by immunoprecipitation from $20 \mu \mathrm{l}$ denatured samples $(6.66 \mu \mathrm{g})$ with polyclonal anti-B-50 antiserum (serum 8502 ), as described previously (De Graan et al., 1989; Dekker et al., 1989b). Immunoprecipitates were subjected to $11 \%$ SDS-PAGE (Kristjansson et al., 1982) and autoradiography. ${ }^{32} \mathrm{P}$-incorporation into B-50 was quantified by densitometric scanning and computer-assisted image analysis of the autoradiograms. ${ }^{32} \mathrm{P}$-incorporation into B-50 is expressed as percentage of KRB- control incubations. Student's $t$ test was used for all statistical comparisons.

\section{Results}

\section{B-50 phosphorylation}

Prelabeling of isolated growth cones for 90 min with ${ }^{32} \mathrm{P}$-orthophosphate leads to the incorporation of ${ }^{32} \mathrm{P}$ into many protein 


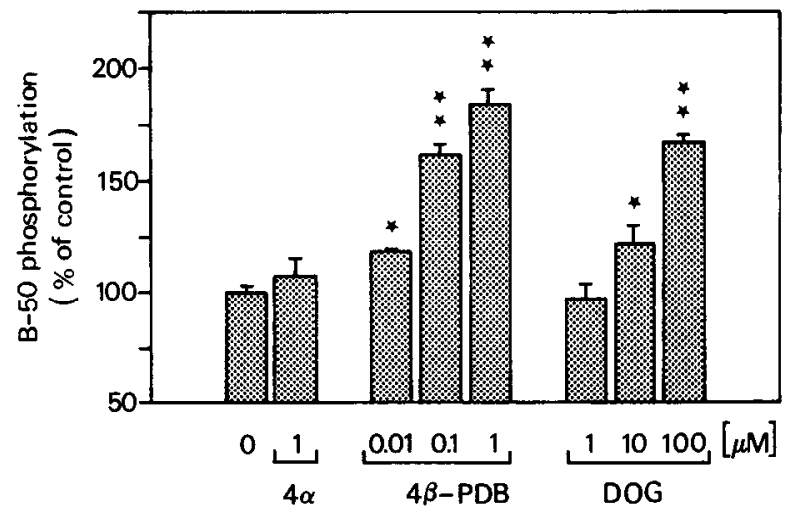

Figure 2. Effects of phorbol diesters and DOG on B-50 phosphorylation. ${ }^{32} \mathrm{P}$-prelabeled growth cones were incubated with several concentrations of $4 \alpha-P D D(4 \alpha, 10 \mathrm{~min}), 4 \beta-P D B(10 \mathrm{~min})$, or $D O G(5 \mathrm{~min})$. ${ }^{32} \mathrm{P}$-incorporation into immunoprecipitated B-50 is expressed as percentage of control incubations without agonists. Data are means \pm SEM $(n \geq 6) .{ }^{* *} p<0.001,{ }^{*} p<0.02$ significantly different from control incubations.

bands (Fig. I). This phosphorylation pattern is notably different from that of synaptosomes, although several phosphobands are found in both preparations (Fig. 1). ${ }^{32}$ P-incorporation into B-50 cannot be quantified directly, since several phosphoproteins comigrate at the $48 \mathrm{kDa}$ position, masking the $\mathrm{B}-50$ band. We, therefore, immunoprecipitated B-50 from the growth cone homogenate. Employing polyclonal anti-B-50 antiserum (serum 8502 ), a single $48 \mathrm{kDa}$ phosphoband was recovered in the immunoprecipitate (Fig. 1, IP), which was absent from preimmune serum controls (Fig. 1, PRE).

To identify B-50 as a physiological substrate of PKC, ${ }^{32} \mathrm{P}$ labeled growth cones were treated with different concentrations of PDB and DOG for $10 \mathrm{~min}$ and $5 \mathrm{~min}$, respectively. B-50 phosphorylation was stimulated in a dose-dependent manner (Fig. 2) to a maximum of $184 \%$ at $10^{-6} \mathrm{M}$ PDB and a maximum of $167 \%$ at $10^{-4} \mathrm{M}$ DOG, when compared to controls. The lowest effective concentrations were $10^{-8} \mathrm{M}$ and $10^{-5} \mathrm{M}$ for PDB and DOG, respectively. At these concentrations, PDB and DOG did not change ${ }^{32} \mathrm{P}$-incorporation into total TCA-precipitated protein. The $4 \alpha$-phorbol, which is inactive with respect to PKC stimulation, did not affect B-50 phosphorylation (Fig. 2).

\section{Potassium-induced depolarization}

Growth cones are known to store neurotransmitter, which they release on depolarization, similar to mature presynaptic nerve endings. In search for a possible involvement of B-50 phosphorylation in this process, we chemically depolarized prelabeled growth cones for different times (Fig. 3). Depolarization with $30 \mathrm{~mm}$ potassium induced a transient increase in B-50 phosphorylation (Fig. 3). The rapid increase was already detectable after $5 \mathrm{sec}$, reached a maximum after $15 \mathrm{sec}(150 \%$ of $5 \mathrm{~mm}$ potassium controls), and was followed by a steady decline to control values within $5 \mathrm{~min}$, despite the continuous presence of $30 \mathrm{~mm}$ potassium. To investigate the contribution of released neurotransmitters to the observed increase in B-50 phosphorylation, we isolated growth cones from neonatal rat cortex, which is rich in cholinergic terminals. It is expected that in this fraction a great number of growth cones will release acetylcholine under depolarizing conditions. Incubation of these cortical growth cones with $10^{-5} \mathrm{M}$ of the muscarinic antagonist atropine reduced the depolarization-induced increase in B-50 phosphorylation by

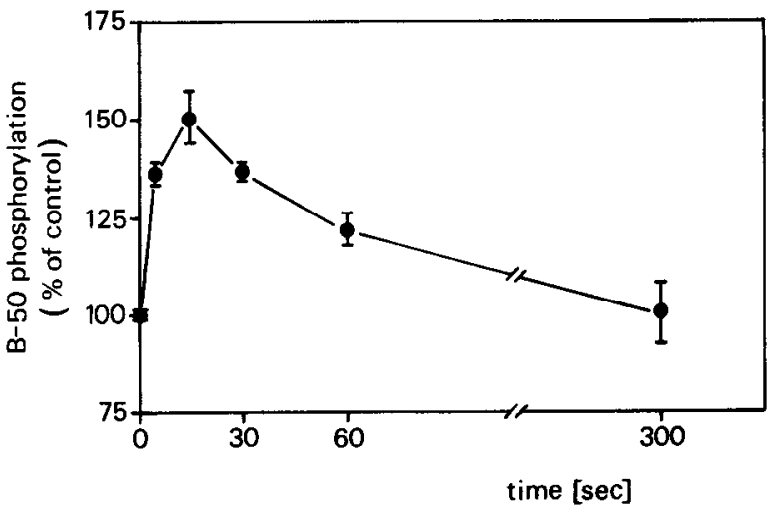

Figure 3. Time course of the effect of $30 \mathrm{~mm} \mathrm{~K}^{+}$on B-50 phosphorylation. ${ }^{32} \mathrm{P}$-incorporation of immunoprecipitated $\mathrm{B}-50$ is expressed as percentage of $5 \mathrm{mM} \mathrm{K}^{+}$controls. Data are means $\pm \operatorname{SEM}(n \geq 6)$.

about $50 \%$ without affecting controls (Fig. 4). Thus, part of the stimulation of B-50 phosphorylation caused by depolarization may be mediated through muscarinic receptor activation.

Higher atropine concentrations $\left(>10^{-5} \mathrm{M}\right)$ further reduced the depolarization-induced rise in B-50 phosphorylation but, in parallel, inhibited B-50 phosphorylation in nondepolarized controls (Fig. 4). Figure 4 illustrates that in the presence of atropine, B-50 phosphorylation is consistently higher under depolarized conditions. This indicates that part of the depolarization-induced increase in B-50 phosphorylation is not mediated through muscarinic receptors.

\section{Effects of carbachol}

The finding that B-50 phosphorylation can be inhibited by atropine prompted us to test the effects of the cholinergic agonist carbachol. Incubation of ${ }^{32} \mathrm{P}$-labeled growth cones with carbachol for $30 \mathrm{sec}$ or $5 \mathrm{~min}$ resulted in a concentration-dependent increase in B-50 phosphorylation under $5 \mathrm{~mm} \mathrm{~K} \mathrm{~K}^{+}$(basal) con-

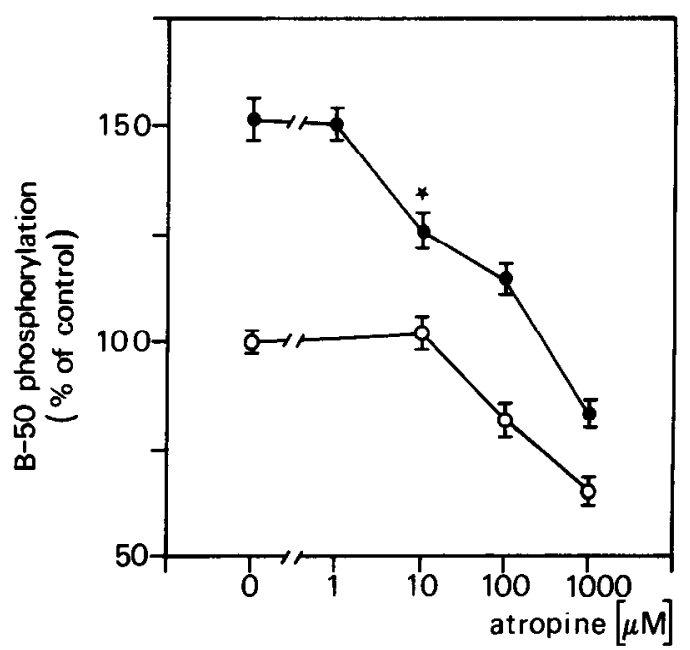

Figure 4. Inhibition of depolarization-induced increase in B-50 phosphorylation by atropine. ${ }^{32} \mathrm{P}$-prelabeled growth cones were incubated with different concentrations of atropine for $5 \mathrm{~min}$. During the last $15 \mathrm{sec}$ of the incubation, $30 \mathrm{mM} \mathrm{K}^{+}$(solid symbols) or $5 \mathrm{mM} \mathrm{K} \mathrm{K}^{+}$ (open symbols) was added. ${ }^{32} \mathrm{P}$-incorporation in immunoprecipitated B-50 is expressed as percentage of control incubations in $5 \mathrm{~mm} \mathrm{~K} \mathrm{~K}^{+}$. Data are means $\pm \operatorname{SEM}(n \geq 6) .{ }^{*} p<0.002$ significantly different from $5 \mathrm{mM} \mathrm{K} \mathrm{K}^{+} / 10 \mu \mathrm{M}$ atropine and from $30 \mathrm{mM} \mathrm{K} \mathrm{K}^{+} / \mathrm{no}$ atropine. 

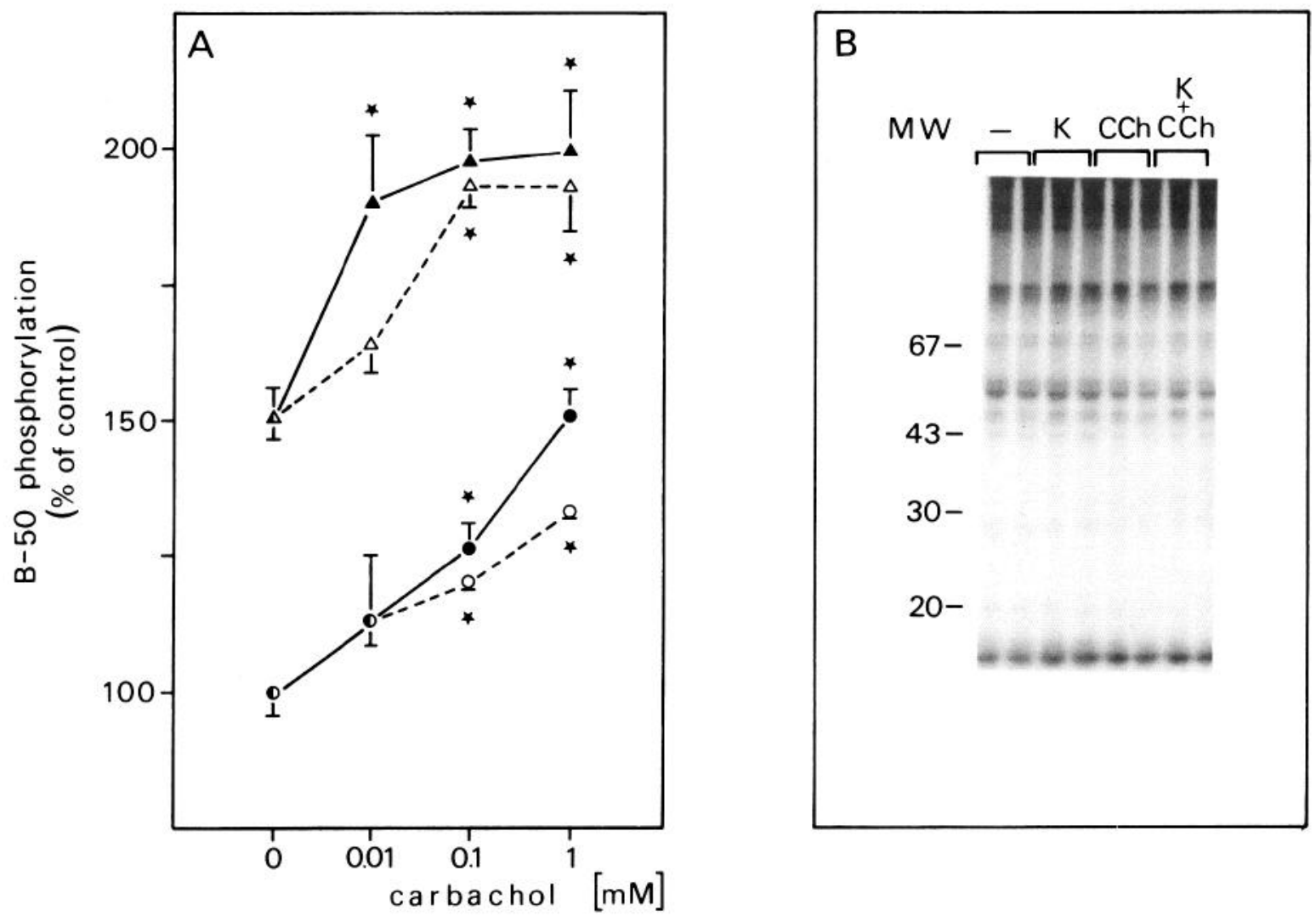

Figure 5. Effect of carbachol with and without $\mathrm{K}^{+}$-depolarization on protein phosphorylation. $A,{ }^{32} \mathrm{P}$-incorporation in $\mathrm{B}-50$ immunoprecipitated from ${ }^{32} \mathrm{P}$-prelabeled growth cones that were incubated with different concentrations of carbachol for $30 \mathrm{sec}$ (solid symbols) or $5 \mathrm{~min}$ (open symbols). During the last $15 \mathrm{sec}$ of the incubation, $\mathrm{K}^{+}$was increased to $30 \mathrm{~mm}$ (triangles) or kept at $5 \mathrm{~mm} \mathrm{~K}^{+}$(circles). ${ }^{32} \mathrm{P}$-incorporation in immunoprecipitated B-50 is expressed as percentage of $5 \mathrm{mM} \mathrm{K} \mathrm{K}^{+}$controls. Data are means $\pm \operatorname{SEM}(n \geq 4) .{ }^{*} p<0.002$ significantly different from 5 mM K ${ }^{+}$(circles) or $30 \mathrm{~mm} \mathrm{~K}^{+}$(triangles) incubations without carbachol. $B$, Autoradiogram of SDS-PAGE-separated homogenate proteins from ${ }^{32} \mathrm{P}$-labeled growth cones, which were exposed to $5 \mathrm{~mm} \mathrm{~K}^{+}(-), 30 \mathrm{mM} \mathrm{K}^{+}(K), 1 \mathrm{~mm}$ carbachol $(C C h)$, or $1 \mathrm{~mm}$ carbachol and $30 \mathrm{mM} \mathrm{K}^{+}(K+C C h)$ as described for panel $A$. Positions of molecular weight markers $(M W)$ are indicated on the left. Note that phosphorylation patterns are not altered by any of the treatments.

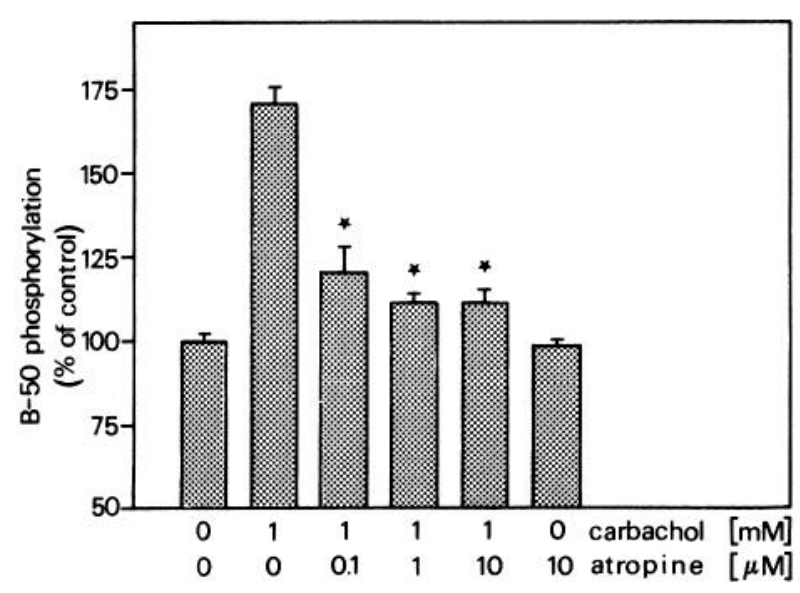

Figure 6. Inhibition of carbachol-stimulated B-50 phosphorylation by atropine. ${ }^{32} \mathrm{P}$-prelabeled growth cones were incubated with different concentrations of atropine for $5 \mathrm{~min}$ at $5 \mathrm{~mm} \mathrm{~K} \mathrm{~K}^{+}$. During the last 30 $\mathrm{sec}$ of the incubation, carbachol was added (1 $\mathrm{mm}$ final concentration). ${ }^{32} \mathrm{P}$-incorporation in immunoprecipitated $\mathrm{B}-50$ is expressed as percentage of control incubations without additions. Data are means \pm SEM $(n=4){ }^{*} p<0.002$ significantly different from incubation with carbachol alone. ditions (Fig. $5 A$ ). Maximal stimulation was observed after a 30 sec treatment with $10^{-3} \mathrm{M}$ carbachol (51\% over controls), the highest concentration tested. The stimulation of B-50 phosphorylation by carbachol was slightly lower after a 5 min than after a $30 \mathrm{sec}$ stimulation (Fig. $5 \mathrm{~A}$ ). The increase in B-50 phosphorylation during carbachol treatment ( $30 \mathrm{sec}$ or $5 \mathrm{~min}$ ) was augmented by $\mathrm{K}^{+}$-depolarization during the last $15 \mathrm{sec}$ of the carbachol treatment. In combination with depolarization, $10^{-5} \mathrm{M}$ carbachol $(30 \mathrm{sec})$ already produced maximal stimulation $(90 \%$ over nondepolarized controls), which is about $40 \%$ higher than the maximal stimulation observed with carbachol alone. This indicates that $10^{-3} \mathrm{M}$ carbachol alone does not fully activate the $\mathrm{PKC} / \mathrm{B}-50$ signal. The incorporation of ${ }^{32} \mathrm{P}$ in TCA-precipitated growth cone proteins from samples $(n=4)$ treated with carbachol $(38,077 \pm 212 \mathrm{CPM} / \mu \mathrm{g}), \mathrm{K}^{+}$-depolarization $(38,163 \pm$ $598 \mathrm{CPM} / \mu \mathrm{g})$, or both $38,220 \pm 271 \mathrm{CPM} / \mu \mathrm{g}$ ) is not different from controls $(38,166 \pm 442 \mathrm{CPM} / \mu \mathrm{g})$, nor is any difference seen as a result of these treatments in phosphorylation pattern of SDS-PAGE-separated total growth cone proteins (Fig. $5 B$ ). Apparently, these treatments do not affect overall kinase activity but specifically stimulate B- 50 phosphorylation.

To establish the involvement of muscarinic receptors in the carbachol-stimulated B-50 phosphorylation, we tried to antag- 
onize the carbachol effect with atropine. The increase in B-50 phosphorylation induced by $10^{-3} \mathrm{M}$ carbachol $(30 \mathrm{sec}$ ) could be prevented almost completely by $10^{-5}-10^{-7} \mathrm{M}$ atropine added $4.5 \mathrm{~min}$ before the carbachol (Fig. 6). At these concentrations, atropine had no effect on the degree of B-50 phosphorylation in noncarbachol-treated controls.

\section{Discussion}

During developmental outgrowth and regeneration of neurites, B-50 is synthesized at very high levels (Kalil and Skene, 1986; Verhaagen et al., 1986; Benowitz and Routtenberg, 1987; Zwiers et al., 1987). The growth-associated expression of the B-50 protein has led to the hypothesis that attributes a prominent role to B-50 in the process of neurite outgrowth and neuronal differentiation (Levine et al., 1981). We have previously presented evidence that the phosphorylation of B- 50 by PKC is implicated in signal transduction at the growth cone membrane (Van Hooff et al., 1988) and in adult brain synaptic plasma membranes (Gispen et al., 1985). During this study we monitored the degree of phosphorylation of the PKC substrate B-50 to establish its involvement in signal transduction in intact growth cones.

In adult brain neurons, $\mathrm{K}^{+}$-depolarization is known to induce changes in the phosphorylation of several proteins (Dunkley and Robinson, 1986), including synapsin I, the $87 \mathrm{kDa}$ PKC substrate protein (Dunkley et al., 1986; Wang et al., 1988) and B-50 (Dekker et al., 1989a, b). Not unexpectedly, therefore, $\mathrm{K}^{+}$depolarization also induces an increase of B-50 phosphorylation in growth cones (Fig. 3). The transient nature of this effect despite persistent depolarization is very similar to that observed in synaptosomes (Dekker et al., 1989b). This increase in B-50 phosphorylation is PKC mediated because it has been shown in hippocampal slices (Dekker et al., 1989a), in synaptosomes (Dekker et al., 1989b), and in intact growth cones (P. N. E. De Graan, unpublished observations) that the $\mathrm{K}^{+}$-induced increase can be blocked by PKC inhibitors polymyxin B and $\mathrm{H} 7$. The involvement of other kinases seems highly unlikely because in all intact and membrane systems studied so far, B-50 is only phosphorylated by PKC (Aloyo et al., 1983; Van Hooff et al., 1986, 1988; De Graan et al., 1988). In addition, we recently have identified serine 41 in the B-50 sequence as the only phosphorylation site (Nielander et al., 1987; Schrama et al., 1988). Although all our data point to a depolarization-induced increase in PKC activity, resulting in an increase in B-50 phosphorylation, we cannot rule out a concurring effect of depolarization on B-50 phosphatase activity.

The increase in B-50 phosphorylation may be elicited directly by depolarization or indirectly by neurotransmitters, released on depolarization. Indeed, the muscarinic antagonist atropine dose-dependently inhibits high $\mathrm{K}^{+}$-induced B-50 phosphorylation in growth cones, isolated from cerebral cortex (Fig. 4). This suggests that at least part of the high $\mathrm{K}^{+}$-effect is mediated through muscarinic receptor activation by released endogenous acetylcholine. Surprisingly, high concentrations of atropine also reduce B-50 phosphorylation under nondepolarizing conditions (Fig. 4). This may either point to spontaneous acetylcholine release under control condition, as observed in growth cones in tissue culture (Young and Poo, 1983), or may be caused by transmitter leakage from damaged growth cones. Since inhibition is only observed at high concentrations of the drug, it may also relate to nonspecific atropine effects. The finding that the presence of atropine reverses only part of the depolarizationinduced B-50 phosphorylation and that, in the presence of atro- pine, depolarized samples are consistently higher than controls indicates that neurotransmitters other than acetylcholine also act through stimulation of PKC. Alternatively, depolarization itself may directly stimulate PKC.

The contribution of released acetylcholine to the depolarization effect is further corroborated by direct stimulation of B-50 phosphorylation by the cholinergic agonist carbachol (Figs. 5.46 ). The dose-response curve of the effect of carbachol on $\mathrm{B}-50$ phosphorylation in growth cones is similar to that reported for carbachol-induced $\mathrm{IP}_{3}$ formation in synaptosomes (Audigier et al., 1988). Since the carbachol-induced stimulation of B-50 phosphorylation can be inhibited by atropine, the effect seems to be mediated through muscarinic receptors. Receptor-mediated formation of $\mathrm{IP}_{3}$ has not yet been reported in growth cones, although the machinery for an $\mathrm{IP}_{3}$ response appears to be present (Garofalo and Pfenninger, 1986). Since a strong coupling has been described between muscarinic receptor activation and PPI response in 1-d-old rat cortex slices (Heacock et al., 1987), it is likely that breakdown of PPIs underlies the observed increase in B-50 phosphorylation. Noteworthy is the observation that the effects of carbachol and depolarization are additive (Fig. 5A). Carbachol treatment under depolarizing conditions reaches maximal stimulation of the $\mathrm{PKC} / \mathrm{B}-50$ signal at a low concentration $\left(10^{-5} \mathrm{M}\right)$, whereas under basal conditions, $10^{-3}$ M carbachol may not even produce maximal stimulation (Fig. $5 A$ ). This indicates that depolarization-induced release of endogenous acetylcholine adds to the effect of carbachol by further saturating muscarinic receptors, thereby achieving maximal B-50 phosphorylation. Alternatively, depolarization and carbachol may stimulate PKC through separate mechanisms, or depolarization may intensify the coupling of the muscarinic receptor to its effector system, as suggested by Eva and Costa (1986).

The physiological significance of B-50 phosphorylation is not known at present. We have proposed that PKC-mediated B-50 phosphorylation is involved in a negative feedback mechanism in receptor-mediated PPI hydrolysis (Gispen et al., 1985). According to this hypothesis, phosphorylated B-50 inhibits phosphatidylinositol 4-phosphate (PIP)-kinase activity, thus reducing the amount of phosphatidylinositol 4,5-bisphosphate $\left(\mathrm{PIP}_{2}\right)$ available for further hydrolysis. In line with this hypothesis, we found an inverse relationship between B-50 phosphorylation and $\mathrm{PIP}_{2}$ labeling in growth cone membranes (Van Hooff et al., 1988). A PKC-mediated negative feedback on muscarinic receptor activation has been proposed in many systems $(\mathrm{El}-\mathrm{Fa}$ kahany et al., 1988), including rat hippocampal slices (Labarca et al., 1984; Schrama et al., 1986), but is merely based on the inhibitory effect of phorbol diesters. Our data provide the first direct evidence that muscarinic receptor activation stimulates PKC activity, resulting in an increase in B-50 phosphorylation. Whether, according to the feedback hypothesis, a sustained increase in $\mathrm{B}-50$ phosphorylation dampens the $\mathrm{IP}_{3}$ response in growth cones remains to be shown.

\section{References}

Aloyo, V. J., H. Zwiers, and W. H. Gispen (1983) Phosphorylation of B-50 protein by calcium-activated, phospholipid-dependent protein kinase and B-50 protein kinase. J. Neurochem. 41: 649-653.

Audigier, S. M. P., J. K. T. Wang, and P. Greengard (1988) Membrane depolarization and carbamylcholine stimulate phosphatidylinositol turnover in intact nerve terminals. Proc. Natl. Acad. Sci. USA. 85: 2859-2863.

Batty, I. R., S. R. Nahorski and R. F. Irvine (1985) Rapid formation of inositol 1,3,4,5-tetrakisphosphate following muscarinic receptor stimulation of rat cerebral cortical slices. Biochem. J. 232: 211-215. 
Benowitz, L. I., and A. Routtenberg (1987) A membrane phosphoprotein associated with neural development, axonal regeneration, phospholipid metabolism, and synaptic plasticity. TINS 12:527-532.

Bradford, M. M. (1976) A rapid and sensitive method for the quantification of microgram quantities of protein utilizing the principle of protein-dye binding. Analyt. Biochem. 72: 248-254.

Brown, E., D. A. Kendall, and S. R. Nahorski (1984) Inositol phospholipid hydrolysis in rat cerebral cortical slices: I receptor characterization. J. Neurochem. 42: 1379-1387.

Cohan, C. S., and S. B. Kater (1986) Suppression of neurite elongation and growth cone dynamics by electrical activity. Science 232: 16381640.

Cohan, C. S., J. A. Connor, and S. B. Kater (1987) Electrically and chemically mediated increases in intracellular calcium in neuronal growth cones. J. Neurosci. 7: 3588-3599.

Davis, G. E., S. Varon, E. Engvall, and M. Manthorpe (1985) Substratum-binding neurite-promoting factors: Relationships to laminin. Trends Neurosci. 8: 528-532.

De Graan, P. N. E., C. O. M. Van Hooff, B. C. Tilly, A. B. Oestreicher, P. Schotman, and W. H. Gispen (1985) Phosphoprotein B-50 in nerve growth cones from fetal rat brain. Neurosci. Lett. 61: 235-241.

De Graan, P. M. E., L. V. Dekker, M. De Wit, L. H. Schrama, and W. H. Gispen (1988) Modulation of B-50 phosphorylation and polyphosphoinositide metabolism in synaptic plasma membranes by protein kinase C, phorbol diesters and ACTH. J. Recept. Res. 8: 345361.

De Graan, P. N. E., L. V. Dekker, A. B. Oestreicher, L. Van Der Voorn, and W. H. Gispen (1989) Determination of changes in the phosphorylation state of the neuron-specific protein kinase $C$ substrate B-50 (GAP43) by quantitative immunoprecipitation. J. Neurochem. 52: 17-23.

Dekker, L. V., P. N. E. De Graan, D. H. G. Versteeg, A. B. Oestreicher, and W. H. Gispen (1989a) Phosphorylation of B-50 (GAP43) is correlated with neurotransmitter release in rat hippocampal slices. J. Neurochem. 52: 24-30.

Dekker, L. V., P. N. E. De Graan, M. De Wit, J. J. H. Hens, A. B. Oestreicher, and W. H. Gispen (1989b) Potassium-induced phosphorylation of the protein kinase $\mathrm{C}$ substrate B-50 in rat cortex synaptosomes. J. Neurochem. (in press).

Dunkley, P. R., and P. J. Robinson (1986) Depolarization-dependent protein phosphorylation in synaptosomes: Mechanisms and significance. Prog. Brain Res. 69: 273-293.

Dunkley, P. R., C. M. Baker, and P. J. Robinson (1986) Depolarization-dependent protein phosphorylation in rat cortical synaptosomes: Characterization of active protein kinases by phosphopeptide analysis of substrates. J. Neurochem. 46: 1692-1703.

Dunkley, P. R., J. A. P. Rostas, J. W. Heath, and D. A. Powis (1987) The preparation and use of synaptosomes for studying secretion of catecholamines. In In Vitro Methods for Studying Secretion, A. Poisner and J. M. Trifaro, eds., pp. 315-334.

El-Fakahany, E. E., B. E. Alger, W. S. Lai, T. A. Pittler, P. F. Worley, and J. M. Baraban (1988) Neuronal muscarinic responses: Role of protein kinase C. FASEB J. 2: 2575-2583.

Ellis, L., F. Katz, and K. H. Pfenninger (1985) Nerve growth cones isolated from fetal rat brain. II. Cyclic adenosine $3^{\prime}, 5^{\prime}$-monophosphate (cAMP)-binding proteins and cAMP-dependent phosphorylation. J. Neurosci. 6: 1393-1401.

Eva, C., and E. Costa (1986) Potassium ion facilitation of phosphoinositide turnover activation by muscarinic receptor agonists in rat brain. J. Neurochem. 46: 1429-1435.

Fisher, S. K., and B. W. Agranoff (1980) Calcium and the muscarinic synaptosomal phospholipid labeling effect. J. Neurochem. 34: 12311240.

Garofalo, R. S., and K. H. Pfenninger (1986) Phosphatidylinositol turnover in nerve growth cones isolated from the CNS. J. Cell Biol. 103: 454a.

Gispen, W. H., C. J. Van Dongen, P. N. E. De Graan, A. B. Oestreicher, and $H$. Zwiers (1985) The role of phosphoprotein B-50 in phosphoinositide metabolism in brain synaptic plasma membranes. In Inositol and Phosphoinositides, J. E. Bleasdale, G. Hauser, and J. Eichberg, eds., pp. 399-413, Humana Press, Clifton, New Jersey.

Gordon-Weeks, P. R. (1987) The cytoskeletons of isolated, neuronal growth cones. Neuroscience 21: 977-989.

Gordon-Weeks, P. R., and R. O. Lockerbie (1984) Isolation and partial characterization of neuronal growth cones from neonatal rat forebrain. Neuroscience 13: 119-136.

Gordon-Weeks, P. R., R. O. Lockerbie, and B. R. Pearce (1984) Uptake and release of $\left[{ }^{3} \mathrm{H}\right]$ GABA by growth cones isolated from neonatal rat brain. Neurosci. Lett. 52: 205-210.

Gunderson, R. W., and J. N. Barrett (1980) Characterization of the turning response of dorsal root neurites toward nerve growth factor. J. Cell Biol. 87: 546-554.

Haydon, P. G., D. P. McCobb, and S. B. Kater (1984) Serotonin selectively inhibits growth cone dynamics and synaptogenesis of specific identified neurons. Science 226: 561-564.

Heacock, A. M., S. K. Fisher, and B. W. Agranoff (1987) Enhanced coupling of neonatal muscarinic receptors in rat brain to phosphoinositide turnover. J. Neurochem. 48: 1904-1911.

Hume, R. I., L. W. Role, and G. D. Fischbach (1983) Acetylcholine release from growth cones detected with patches of acetylcholine receptor-rich membranes. Nature 305: 632-634.

Hyman, C., and K. H. Pfenninger (1987) Intracellular regulators of neuronal sprouting: II Phosphorylation reactions in isolated growth cones. J. Neurosci. 7: 4076-4083.

Jope, R. S., T. L. Casebolt, and G. V. W. Johnson (1987) Modulation of carbachol-stimulated inositol phospholipid hydrolysis in rat cerebral cortex. Neurochem. Res. 12: 693-700.

Kalil, K., and J. H. P. Skene (1986) Elevated synthesis of an axonally transported protein correlates with axon outgrowth in normal and injured pyramidal tracts. J. Neurosci. 6: 2563-2570.

Kapfhammer, J. P., and J. A. Raper (1987) Collapse of growth cone structure on contact with specific neurites in culture. J. Neurosci. 7; 201-212.

Kater, S. B., M. P. Mattson, C. Cohan, and J. Connor (1988) Calcium regulation of the neuronal growth cone. Trends Neurosci. 11: 315321 .

Katz, F., L. Ellis, and K. H. Pfenninger (1985) Nerve growth cones isolated from fetal rat brain III. Calcium-dependent protein phosphorylation. J. Neurosci. 5: 1402-1411.

Kendall, D. A., and S. R. Nahorski (1984) Inositol phospholipid hydrolysis in rat cerebral cortical slices: II Calcium requirement. I. Neurochem. 42: 1388-1394.

Kristjansson, G. I., H. Zwiers, A. B. Oestreicher, and W. H. Gispen (1982) Evidence that the synaptic phosphoprotein B-50 is localized exclusively in nerve tissue. J. Neurochem. 39: 371-378.

Labarca, R., A. Janowsky, J. Patel, and S. M. Paul (1984) Phorbol esters inhibit agonist-induced [ $\left.{ }^{3} \mathrm{H}\right]$ inositol-1-phosphate accumulation in rat hippocampal slices. Biochem. Biophys. Res. Commun. 123: 703-709.

Levine, J., P. Skene, and M. Willard (1981) GAPs and fodrin novel axonally transported proteins. Trends Neurosci. 4: 273-277.

Lockerbie, R. O., and P. R. Gordon-Weeks (1985) $\gamma$-Aminobutyric acid (GABAa) receptors modulate $\left[{ }^{3} \mathrm{H}\right] \mathrm{GABA}$ release from isolated neuronal growth cones in the rat brain. Neurosci. Lett. 55: 273-277.

Lockerbie, R. O., P. R. Gordon-Weeks, and P. R. Pearce (1985) Growth cones isolated from developing rat forebrain: Uptake and release of GABA and noradrenaline. Dev. Brain Res. 21: 265-275.

Lockerbie, R. O., D. Herve, G. Blanc, J.-P. Tassin, and J. Glowinski (1988a) Isolated neuronal growth cones from developing rat forebrain possess adenylate cyclase activity which can be augmented by various receptor agonists. Dev. Brain Res. 38: 19-25.

Lockerbie, R. O., J.-C. Beaujouan, M. Saffroy, and J. Glowinsky (1988b) An isolated growth cone-enriched fraction from developing rat brain has substance $P$ binding sites. Dev. Brain Res. 40: 1-9.

Mattson, M. P. (1988) Neurotransmitters in the regulation of neuronal cytoarchitecture. Brain Res. Rev. 13: 179-212.

Meiri, K. F., K. H. Pfenninger, and M. B. Willard (1986) Growthassociated protein, GAP43, a polypeptide that is induced when neurons extend axons, is a component of growth cones and corresponds to pp46, a major polypeptide of a subcellular fraction enriched in growth cones. Proc. Natl. Acad. Sci. USA 83: 3537-3541.

Nielander, H. B., L. H. Schrama, A. J. Van Rozen, M. Kasparaitis, A. B. Oestreicher, P. N. E. De Graan, W. H. Gispen, and P. Schotman (1987) Primary structure of the neuron-specific phosphoprotein B-50 is identical to growth-associated protein GAP43. Neurosci. Res. Commun. 1: 163-172.

Pfenninger, K. H., C. Hyman, and R. S. Garofalo (1986) Protein phosphorylation in the nerve growth cone. Prog. Brain Res. 69: 235243. 
Schrama, L. H., P. N. E. De Graan, J. Eichberg, and W. H. Gispen (1986) Feedback control of the inositol phospholipid response in rat brain is sensitive to ACTH. Eur. J. Pharmacol. 121: 403-404.

Schrama, L. H., P. N. E. De Graan, L. V. Dekker, A. B. Oestreicher, H. Nielander P. Schotman, and W. H. Gispen (1988) Functional significance and localization of phosphosite(s) in the neuron-specific protein B-50/GAP43. Soc. Neurosci. Abstr. 14: 197.15.

Skene, J. H. P., R. D. Jacobson, G. J. Snipes, C. B. McGuire, J. J. Norden, and J. A. Freeman (1986) A protein induced during nerve growth (GAP43) is a major component of growth cone membranes. Science 233: 783-786.

Van Hooff, C. O. M., P. N. E. De Graan, J. Boonstra, A. B. Oestreicher, M. H. Schmidt-Michels, and W. H. Gispen (1986) Nerve growth factor enhances the level of the protein kinase C substrate B-50 in pheochromocytoma PC12 cells. Biochem. Biophys. Res. Commun. 139: 644-651.

Van Hooff, C. O. M., P. N. E. De Graan, A. B. Oestreicher, and W. H. Gispen (1988) B-50 phosphorylation and polyphosphoinositide metabolism in nerve growth cone membranes. J. Neurosci. 8: 17891795.

Van Lookeren Campagne, M., A. B. Oestreicher, P. M. P. Van Bergen en Henegouwen, and W. H. Gispen (1989) Ultrastructural immunocytochemical localization of B-50/GAP43, a protein kinase C substrate, in isolated presynaptic nerve terminals and neuronal growth cones. J. Neurocyt. (in press).
Verhaagen, J., C. O. M. Van Hooff, P. M. Edwards, P. N. E. De Graan, A. B. Oestreicher, F. G. I. Jennekens, and W. H. Gispen (1986) The kinase $C$ substrate protein B-50 and axonal regeneration. Brain Res. Bull. 17: 737-741.

Wang, J. K. T., S. I. Walaas, and P. Greengard (1988) Protein phosphorylation in nerve terminals: Comparison of calcium/calmodulindependent and calcium/diacylglycerol-dependent systems. J. Neurosci. 8: 281-288.

Weiss, S., B. H. Schmidt, M. Sebben, D. E. Kemp, J. Bockaert, and F. Sladeczek (1988) Neurotransmitter-induced inositol phosphate formation in neurons in primary culture. J. Neurochem. 50: 1425-1433.

Young, S. H., and M.-M. Poo (1983) Spontaneous release of transmitter from growth cones of embryonic neurons. Nature 305: 634637.

Zwiers, H., H. D. Veldhuis, P. Schotman, and W. H. Gispen (1976) ACTH, cyclic nucleotides and brain protein phosphorylation in vitro. Neurochem. Res. 1: 669-677.

Zwiers, H., A. B. Oestreicher, M. A. Bisby, P. N. E. De Graan, and W. H. Gispen (1987) Protein kinase C substrate B-50 in adult and developing rat brain is identical to axonally transported GAP43 in regenerating peripheral rat nerve. In Axonal Transport, R. Smith and M. Bisby, eds., pp. 421-433, Liss, New York. 